\title{
Entrapped Thrombus in a Patent Foramen Ovale with Dyslipidemia
}

\author{
Dislipidemisi olan Patent Foramen Ovaleli Bir Olguda Yerleşik Trombüs
}

Mehmet Akif Cakar', Ramazan Akdemir', Mehmet Bulent Vatan', Huseyin Gunduz'

'Sakarya University Faculty Of Medicine, Department Of Cardiology

Özet

Rutin otopsiye giden sağlıklı bireylerin yaklaşık \%27'sinde, transesofageyal ekokardiyografi yapılan genel popülasyonun \% 25 sinde patent foramen ovale tepit edilir. PFO genelde benign bir durum olup, ancak inme, migren ve dalgıç ekompresyon hastalıkları ile ilişkili olduğuda düşünülmektedir. Biz 49 yaşında PFO lu foramen ovaleye yerleşik trombüsü olan bir olgu sunduk.

Anahtar Kelimeler: Yerleşik trombüs, patent foramen ovale

Başvuru Tarihi: 03.03.2013

Kabul Tarihi: 12.03.2013

\section{Abstract}

Patent foramen ovale (PFO) is identified in approximately $27 \%$ of healthy individuals undergoing routine autopsy and in $25 \%$ of the general population on transesophageal echocardiography (TEE). PFO generally considered benign, but has been associated with stroke, migraine and diving decompression sickness. We presented a 49-year-old woman in which a thrombus was entrapped in a patent foramen ovale

Keywords: Entrapped thrombus, Patent foramen ovale

Aplication: 03.03.2013 Accepted: 12.03.2013

\section{Introducion}

Patent foramen ovale (PFO) is identified in approximately $27 \%$ of healthy individuals undergoing routine autopsy and in $25 \%$ of the general population on transesophageal echocardiography (TEE). PFO generally considered benign, but has been associated with stroke, migraine and diving decompression sickness ${ }^{1}$.

A 49-year-old woman with a history of migraine was referred to our clinic for PFO. Transthoracic echocardiography showed a suspicion of a patent foramen ovale. For better delineation of the PFO, we performed transesophageal echocardiography, which showed an 8x9-mm mobile thrombus entrapped in patent foramen ovale and floating in the orifice of the PFO tunnel. (Fig. 1,2).
Figure 1 : Transesophageal echocardiographic images obtained from bicaval view showing thrombus entrapped in patent foramen ovale.

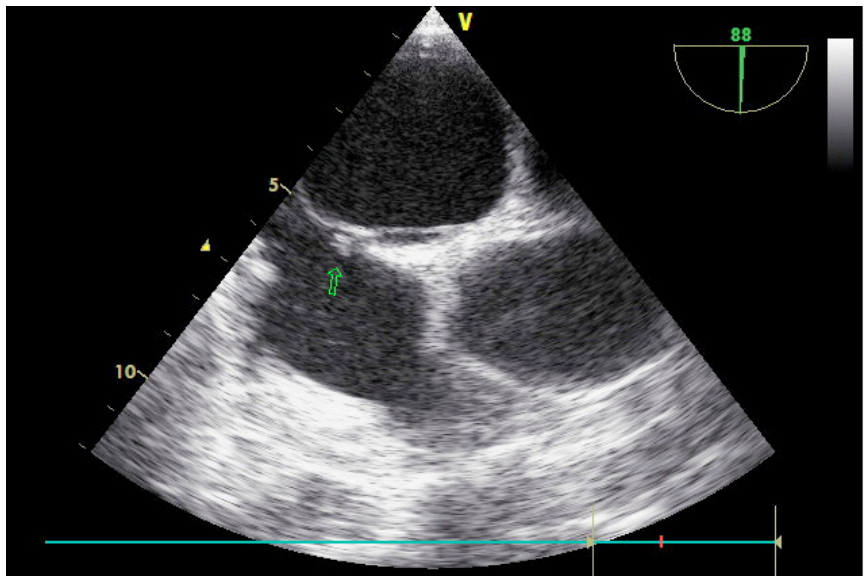


Figure 2 : Transesophageal echocardiographic images showing a narrow color flow jet passing through the right atrium to the left atrium.

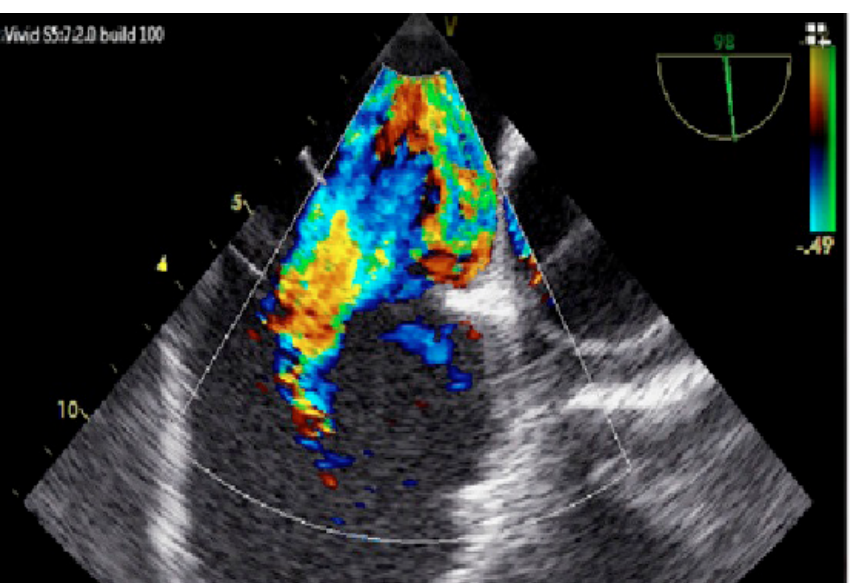

Biochemical test results were normal other than dyslipidemia (trigliserid level 1050mg/dl, HDL 26 mg/dl). Dysli-

\section{References}

1. Torbey $E$, Thompson PD Patent foramen ovale: thromboembolic structure or incidental finding? Conn Med (2011) 75: 97-105

2. Doggen CJ, Smith NL, Lemaitre RN, Heckbert SR, Rosendaal FR, Psaty BM. Serum lipid levels and the risk of venous thrombosis. Arterioscler Thromb Vasc Biol. 2004 Oct;24(10):1970-5. Epub 2004 Aug 26 pidemic patients have increased protrombotic factors. Hovewer, Doggen et al. reported that elevated triglyceride levels were associated with a doubling risk of venous thrombosis in postmenopausal women whereas elevated HDL cholesterol levels were associated with a decreased risk. ${ }^{2}$. The authors explain their results with an interaction of triglycerides with different coagulant factors such as activated protein C (APC), factor VIIC, factor VIII, factor IX, and fibrinogen. Karasek et al. showed increased levels of PAl-1 and t-PA in patients with hypertrigliseridemia ${ }^{3}$

Here, we suggest that the association of low HDL cholesterol level and hypertriglyceridemia with thrombosis might be explained in part by dyslipidemia leads to a procoagulant state due to increased coagulant factors and higher blood viscosity that causes thrombus formation

3. Karasek D, Vaverkova H, Halenka M, Jackuliakova D, Frysak Z, Slavik L, Novotny D

4. Prothrombotic markers in asymptomatic dyslipidemic subjects $J$ Thromb Thrombolysis. 2011 Jan;31(1):27-36. 